\title{
J ob Satisfaction as a Determinant of Effective Performance on Academic Staff in Selected Public and Private Universities in Mongolia
}

\author{
Tsogtsuren Bayasgalan*
}

\begin{abstract}
The aim of this study is to analyze the requirements for effective performance of employees in higher educational institutions of Mongolia. This paper proposed the use of organizational OCTAPACE /Openness, Confrontation, Trust, Authenticity, Pro-active, Autonomy, Collaboration; Experimentation/ culture and workplace structure models evaluate job satisfaction and commitment of academic staff. An organizational OCTAPACE culture model is a fairly new concept and experience in Mongolia. This model has been studied and is wellknown in India, Malaysia and western countries. In Mongolia the subject of study has been developed at a low level. This study proposed that an employee' job satisfaction and commitment influence the effective performance of the overall educational institution. Data analysis results indicated that OCTAPACE culture influences job satisfaction and commitment, workplace structure (support, supervisor support) as well as significantly influencing on the job satisfaction and commitment. Based on the collected data, job satisfaction and organizational commitment significantly influence job performance. Mongolia has 17 public and 94 private universities (Mongolian ministry of education, culture and science website). In terms of participants in this study, a theoretical and empirical survey conducted in 160 Mongolian public and in 143 private universities including university professors. Data was estimated by SPSS 21 and Smart PLS 2.0 statistic programs.
\end{abstract}

Keywords: OCTAPACE, workplace structure, job satisfaction, organizational commitment.

\footnotetext{
* Tsogtsuren Bayasgalan is a Ph.D student at Public Administration department, College of Political Science and Economics, Korea University. E-mail: happyjoymada@gmail.com, bayasaa@korea.ac.kr.
}

Manuscript received February 12, 2015; out for review March 17, 2015; review completed April 1, 2015; accepted April 12, 2015.

The Korean Journal of Policy Studies, Vol. 30, No. 1 (2015), pp. 115-145.

(C) 2015 by the GSPA, Seoul National University 


\section{INTRODUCTION}

The collapse of the Soviet Union and the Council for Mutual Economic Assistance brought fundamental changes to Mongolia. The education sector was not an exception. Twelve reforms were implemented aimed at improving the efficiency and effectiveness of education through "rationalization and decentralization" (Weidman, 2002).

Mongolian higher education went through a significant philosophical and pedagogical paradigm shift during that time, including the privatization of higher education institutions and the introduction of tuition fees (Bat-Erdene, Costa, and Yeager, 1996). According to Bat-Erdene, Costa, and Yeager (1996), however, the Education Ministry did not have enough capacity to implement the reforms to their full potential. The policy program issues focused mainly on technical and finance. Financing education was also difficult during this period. In 1990, education received the largest share of the government expenditure (18.5 percent, as calculated by the Asian Development Bank, 2008) and the education sector employed more than 10 percent of the workforce (Wu, 1994).

Mongolia passed a series of laws in 1995 beginning with the Mongolian Government Education Policy that addressed ways for Mongolia to overcome their short-term crisis in education while maintaining development, and creating a new educational system that would facilitate the growth of intellectual factors that would help in transitioning Mongolian (John C Weidman and Brain Yoder, 2010) higher education institutions. A reform and development policy program has been implemented by Mongolian government since 2012. This policy program covers three levels of education structure elementary, middle and high school, and tertiary education. The policy program dealt mostly with emergent issues but there was no mention about teachers, professor job satisfaction, and its influences on their effective performance in the program. In Mongolia, an understanding of job satisfaction and effective performance of the employees has been increased more and more in past several years.

Job satisfaction and effective performance of the employees within an organization is of vital concern for organizational management in order to achieve goals and objectives.

This study examined the relationship and interaction of effectiveness of performance and job satisfaction in public and private university's staff of Mongolia. A wide range of influences has been examined such as organizational culture, workplace structure, organizational behavior, managerial leadership style, and team formation characteristics.

In addition, the terms "job satisfaction" and "effective performance" have been used in human resource management in Mongolia. "Effective people can contribute to the effectiveness of the organization; competent, motivated and satisfied people can make things happen and enable organizations to achieve their goals" (T.V. Rao, 1990). 
Every higher educational system in Mongolia depends heavily on teachers for execution of its programs. Particularly, satisfied teachers can build highly effective performance in their work and projects. The employee's job satisfaction and organizational culture have received significant attention in studies of universities. When teachers are dissatisfied at work, they are less committed to their job and tend to look for other job opportunities. Therefore, higher rates of staff turnover cannot create a good, reliable high effective performance. Job satisfaction is an important attitude in assessing the teacher's intention to stay in an organization. Job satisfaction also is a factor in the overall contribution of the teachers to the university. The result of effective performance of employees' issues in Mongolia which required more subject of study, inevitable changes and significantly emergent for Mongolian higher educational institutions.

A number of studies have found a link between job satisfaction and organizational performance. (Chen and Francesco, 2000; Mathieu and Zajac, 1990; Williams and Hazer, 1986). For example, studies in 2006 and 2011 showed organizational culture and workplace do have a significant influence on job satisfaction and effective performance (Ozer, Benet-Martinez, 2006; Schulman, 2011). Job satisfaction is generally influenced by the organizational culture, workplace structure, organizational behavior, manager's leadership style, team characteristics, and employees' ability (Voon, Lo, Ngui, Ayob 2011). However, the influence of natural organizational culture (OCTAPACE), workplace structure and their subsequent effects on employee job satisfaction and commitment were not explored. Subranmanian (2012) suggested that the organizational culture is behavior and beliefs characteristic of a particular social, ethnic or age group that helps to increase the organizational effectiveness and development. Thus, impact on employee performance and satisfaction.

The eight dimensions of OCTAPACE culture are Openness, Confrontation, Trust, Authenticity, Pro-active, Autonomy, Collaboration, and Experimentation. These dimensions are very essential for a strong and successful organization. These eight dimensions of organizational culture are highly influential to job satisfaction and organizational commitment. Udai Pareek (1992) grouped the Culture-related concepts of OCTAPACE into three basic levels: values, climate, and atmosphere. The culture with OCTAPACE values has had the greater chance of achieving high involvement and satisfaction, teamwork, growth and free flow of communication within the organization (Subranmanian, 2012).

Lawler's (1992) theory of affective attachment provides a theoretical linkage between more immediate positive emotions like satisfaction, and more enduring affective attachments like commitment. According to this theory, the positive emotional states precede affective attachments to collectivities, acting as a mediating factor between social structures and affective attachments (Lawler, 1992). Mueller and Lawler (1996) 
extend these assumptions to the relationship between working conditions, job satisfaction, and organizational commitment. Working conditions are important variables of job satisfaction and commitment, therefore structural variables, such as supervisor support and support positively influence job satisfaction and commitment. A universities' effective performance depends directly on their employees' satisfaction and commitment.

This study examined how four factors: OCTAPACE, workplace structure, commitment and job satisfaction had on effective performance of teachers in public and private universities in Mongolia.

The hypothesis aimed to answer the following question:

1. How has job satisfaction of Mongolian university teachers and professors influenced their work performance?

This study had a threefold proposal. First, I hypothesized that job satisfaction and commitment affect effective performance. Second, I examined the influencing factors on job satisfaction and commitment. Finally, I discussed the results, and offered some comparisons.

\section{THEORITICAL FRAMEWORK AND HYPOTHESIS}

This study proposed that organizational culture and workplace structure are influential in job satisfaction and commitment. I briefly reviewed the literature on organizational culture OCTAPACE, job satisfaction, workplace structure, organizational commitment

Figure 1. Conceptual Model of the Requirements of Job Satisfaction and Commitment

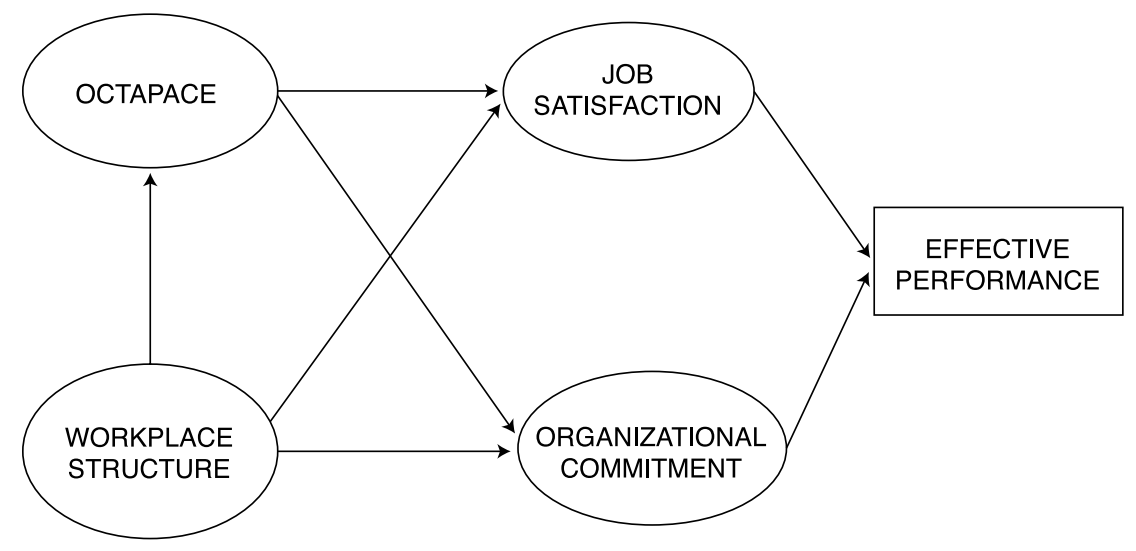


and effective performance and how they are related each other.

The satisfied employees can build effective performance. The conceptual model is drawn in Figure 1.

\section{OCTAPACE determinants of Job Satisfaction and Commitment}

Employee's job satisfaction is most important in the public and private higher educational institutions. Job satisfaction can be defined as an indicator of one's feelings toward work, but satisfaction is multidimensional and influenced by a complex array of personal and situational circumstances (Hagedorn, 2000, Hezberg, 1966; Kalleberg, 1977; Volkwein et al., 1998).

I proposed that requirement of job satisfaction the organizational culture of OCTAPACE. OCTAPACE culture is environmental and deals with the top management commitment to the human resource development in general. According to the Peters and Waterman (1982), organizational culture is patterns of beliefs, rituals, symbols, and myths that evolve over time, serving to reduce human variability and control and shape employee behavior in organizations. Also, to understand the concept of organizational culture Schein's definition was adopted. Schein(1990) defined culture as a pattern of basic assumptions, invented discovered or developed by a given group. As the organization to cope with its problems of external adaptation and internal integration, new members as the correct way to perceive, think and feel in relation to these problems. Scholars suggest that eight dimensions of OCTAPACE culture are Openness, Confrontation, Trust, Authenticity, Pro-active, Autonomy, Collaboration, and Experimentation which are essential for a strong and successful organizational performance.

According to Udai Pareek (1992), the Culture-related concepts also can be seen as multilevel concepts.

"The first level of the core is the values, which give a distinct identity to a group. This is the basic ethos of the group. Pareek defines ethos as "Underlying spirit of character or group and is the root of culture. The second level concept is "climate, which can be defined as the perceived attributes of an organization and its members, groups and issues. The third level concept relates" atmosphere, which is the distinct factor that affects the development of someone or something."

The eight dimensions of OCTAPACE have a greater chance of achieving high involvement and satisfaction, teamwork, growth and free flow of communication within the organization.

They are as follows: 
Openness: How spontaneous are the feelings, thoughts feedback expressed by co-workers?

Openness can be defined as freedom in relationships with other coworkers to share and interact without hesitation. Openness helps to improve communication peer to peer and free interaction among team mates.

Confrontation: How are problems and challenges faced?

Confrontation can be defined as struggling with the problems and challenges without shying from them. Confrontation helps to solve problems by team discussions. Also it fosters a deeper analysis of interpersonal problems.

Trust: Does the organization trust - is the organization worth trusting?

Trust can be defined as ability to share their confidential information privately. Trust supports higher empathy, timely support, and reduced stress.

Authenticity: How to create reflection between feeling, says and doing?

Authenticity can be defined as set of things that a person does, feels and says. Also authenticity is reflected in owing up of mistakes, improves interpersonal communication and reduced distortion in communication.

Pro-action: How to be prepared, to take the initiative or prevent an action? Pro-action helps to face eventualities and adversities. Also pro-action takes initiative, preplanning and taking preventive action.

Autonomy: How to create in one's own sphere, mutual relationships and giving freedom to plan?

Autonomy can be defined as giving freedom to act, respecting individual and role autonomy. Autonomy supports individuals own space, respecting individual and role autonomy.

Collaboration: How to work as team and being supportive for other team members?

Collaboration can be defined as individuals working together. Collaboration helps to solve the problem.

Experimentation: How to encourage innovative approaches to solve problems, taking a fresh look at things?

Experimentation can be defined as working with the resources that encouraging creativity. Experimentation supports feedback for improving and developing of new product and methods. 


\section{Workplace Structure Determinants of Job Satisfaction and Commitment}

Researchers often propose job satisfaction and organizational commitment as intervening variables between other determinants (e.g., structural and individual variables) and outcomes like stay intentions and employee turnover (Iverson, 1992; Mueller et al., 1992). Price and Mueller, (1986a) suggested that the workplace factors which includes peer support and peer supervisor stress are affecting job satisfaction (Burke, 1988; Leong et al., 1996; Sullivan and Bhagat, 1992). The same workplace factors are not consistently related to stress in all workplaces and the relationship between stress and job satisfaction differ depending on the group being investigated (Rees, 1995; Young and Cooper, 1995). Organizational structure change generally affects organizational culture. It was also found that organizational culture takes an important role in increasing job performance. ( Davies, Nutley, et al, 2008).

Many foreign researchers suggested that job satisfaction and organizational commitment are the most important variables on the job performance. In Mongolia, most of the public and private universities were established in the early 1990s. Higher education Institutions experiences with human resources particularly professional knowledge and skills of academic staff's or professors' effective performance directly are the human resource management. Specially, the organization's performance is affected by the employee's job satisfaction. Thus, employees' motivation and attitudes are interrelated with the effective performance.

\section{Effects of OCTAPACE Culture on Job Satisfaction and Performance}

Many researchers suggested that job satisfaction is an important ingredient for evaluating an organization's success. It is an individual matter and the result of various specific attitudes possessed by an employee. According to Akfopure, (2006) the term, job satisfaction refers to the attitudes and feelings people have about their work. Also job satisfaction is defined as the feelings or the general attitude of the employees in relation to their jobs and the job components such as the working environment, working conditions, equitable rewards, and communication with their colleagues (Glisson and Durick, 1988; Kim, 2005). Many studies have been carried out regarding job satisfaction. One such study by Robbins and Judge (2009), describes job satisfaction as a positive feeling about a job, resulting from an evaluation of its characteristics. A person with a high level of job satisfaction holds positive feelings about his or her job, while an unsatisfied person holds negative feelings. Job satisfaction is a pleasurable, positive state resulting from one's job and job experience. (Locke, 1976)

Herzberg et al. (1959) defined the best known popular "theory of job satisfaction." 
According to the two-factor theory of job satisfaction factors that affect job satisfaction are divided into two categories, hygiene and motivation. Hygiene factors surround the doing of the job. They include supervision, interpersonal relations, physical working conditions, salary, company policy and administration, benefits, and job security. Motivation factors lead to positive job attitudes because they satisfy the need for selfactualization. Motivation factors are achievement, recognition, the work itself, responsibility, and advancement. The opposite of satisfaction is no satisfaction. The opposite of dissatisfaction is no dissatisfaction. The satisfaction of hygiene needs can prevent dissatisfaction and poor performance, but only the satisfaction of the motivation factors will bring the type of productivity improvement sought by companies (Herzberg et al., 1959).

Job satisfaction has been correlated with enhanced job performance, positive work values and high levels of employee motivation and lower rates of absenteeism, turnover and burnout. Therefore, organizations should be concerned with the level of satisfaction in their employees and the ultimate aim of those who organize and control workers is satisfaction (Spector, 2003). Job satisfaction has been correlated with enhanced job performance, positive work values, and high levels of employee motivation and lower rates of absenteeism, turnover and burnout (Abraham Maslow, 1970). Therefore, managers should be concerned with the level of satisfaction in their organization and the ultimate aim of those who organize and control workers is satisfaction (Spector, 2003). The idea of job satisfaction is very complicated McCormick and Ilgen (1985). Locke (1976) presented a summary of job dimensions that have been established to contribute significantly to employees' job satisfaction. Satisfaction in one's job means increased commitment in the fulfillment of formal requirements; and is deemed as a pleasurable or positive emotional state resulting from the appraisal of one's job or job experience (Locke, 1969). Job satisfaction measures the employee satisfaction with specific dimensions of the job, such as the work itself, his immediate supervisors, pay, co-workers, and opportunity for promotion (Smith et al. 1965, Kendall and Hulin, 1969).

The multidimensional nature of satisfaction grew out of Herzberg's Two Factor Theory (1966), which drew our attention on the one hand to intrinsic job content factors (such as feelings of accomplishment, recognition, and autonomy) and on the other hand to extrinsic job context factors (such as pay, security, and physical working conditions). Several studies have examined the intrinsic and extrinsic dimensions of job satisfaction in higher education (Austin and Gamson, 1983; Hackman and Lawler, 1971; Hagedorn, 1994; Kalleberg, 1977; Olsen, 1993). Employees may be satisfied with some components of their responsibilities or work environment, but not satisfied with others. They can feel reasonably satisfied with the content of a job, but at the 
same time, frustrated about their potential for growth or mobility within the organization (Kanter, 1977). Volkwein and his colleagues (1998) found empirical support for several important dimensions of administrative satisfaction: intrinsic satisfaction reflecting feelings of accomplishment, autonomy, creativity, initiative, and challenge in job; extrinsic satisfaction reflecting one's attitude toward salary and benefits, opportunities for advancement, and future income potential; satisfaction with work conditions showing one's reaction to work hours, work pressure, job security, and organizational politics; and interpersonal satisfaction reflecting one's relationships with colleagues, faculty, and students.

In addition, to agreeing that job satisfaction is multidimensional, most studies conclude that satisfaction is influenced by a complex array of personal and situational circumstances (Austin and Gamson, 1983; Bruce and Blackburn, 1992; Hoppock, 1977; Mumford, 1972). Herzberg (1966) identified 14 important factors that influence job satisfaction - among them are achievements, recognition, the work itself, responsibility, possibility of advancement, the possibility of growth, salary, job security, interpersonal relations, technical supervision, agree with company policies, and administration, work conditions, and personal life.

Higher education research has shown that several work-related variables exert positive and significant influences on administrative satisfaction: a supportive organizational culture, teamwork, relationships with colleagues and superiors, worker autonomy, and self-fulfillment (Austin and Gamson, 1983; Bensimon and Neumann, 1993; Berwick, 1992; Boone, 1987; Lawler, 1986; Rigg, 1992; Volkwein et al., 1998). Job and workload stress exert negative influences on satisfaction and are almost always included in studies of job satisfaction (Blau, 1993; Blix and Lee, 1991; Glick, 1992).

Udai Pareek (1992) suggested that the eight dimensions of OCTAPACE have a greater chance of achieving high involvement and satisfaction, teamwork, growth and free flow of communication within the organization. The OCTAPACE cultures are most important on job satisfaction and commitment.

Hypothesis 1: Organizational cultures (OCTAPACE) are (Openness, Confrontation; Trust; Authenticity; Pro-Action; Autonomy; Collaboration; Experimentation) positively relate to (a) job satisfaction and (b) organizational commitment.

\section{Workplace Structure Relationship between Commitment and Job Satisfaction}

There are numerous investigations that have studied the relationship between organizational commitment and job satisfaction (Currivan, 1999). Some researchers have admitted that organizational commitment may be an independent variable with job 
satisfaction as an outcome (Bateman and Strasser, 1984; Vandenberg and Lance, 1992). According to Bateman and Strasser (1984) organizational commitment has an effect on job satisfaction, which in turn will affect the turnover intention. These research studies argue that the managers who are highly committed to the organizations may experience higher levels of job satisfaction (Lau and Chong, 2002). Irving, Coleman and Cooper (1997) found that job satisfaction was positively related to affective and normative commitment (with a stronger relation between satisfaction and affective commitment), but not with continuance commitment.

Commitment is interrelated with satisfaction. Becker et al. (1995) in Tella et al. (2007) defined organizational commitment in three dimensions; (1) a strong desire to remain as a member of a particular organization, (2) a willingness to exert high levels of efforts on behalf of the organization and (3) a definite belief in and acceptability of the values and goals of the organization.

In the past research, according to Getahun, Sims \& Hummer (2008), Saari and Judge (2004), Lambert (2004), Malhorta and Mukerjee (2004) discovered a positive association between the two variables. Job satisfaction is so important in that its absence often leads to lethargy and reduced organizational commitment (Moser, 1997). In addition, the work attitudes of job satisfaction and organizational commitment are important in shaping employees' intentions to stay or leave. Both were predicted to have direct effects on turnover intent of employees. Organizational commitment is the bond between the worker and the organization. Employees with high commitment are loyal to the organization, share its values, and identify with the goals of the organization (Mowday, Porter, \& Steers, 1982), (Norizan Ismail, 2012).

In recent years, many scholars defined effective performance and job performance. Job performance is directed to achieving goals of the organization in which a person works. Therefore, the job performance of an individual plays a vital role with their job satisfaction, organizational culture, workplace structure and organizational commitment to an organization's growth. According to Murphy (1989), job performance can be defined as "the set of behaviors that are relevant to the goals of the organization or the organizational unit in which a person works." Borman and Motowidlo (1993) divided performance into task and contextual performance. Task performance was defined as the effectiveness with which job incumbents perform activities that contribute to the organization's technical core (Borman and Motowidlo, 1997). Contextual performance was defined as performance that is not formally required as part of the job, but that helps shape the social and psychological context of the organization (Borman and Motowidlo, 1993).

Hussin (2011), determine the level of job satisfaction and job performance and to identify the relationship between job satisfaction components (which are pay, promotion, 
the work itself, supervision, and co-workers) and job performance among employees of companies. Job performance consists of the observable behaviors that people do in their jobs that are relevant to the goals of the organization (Campbell, McHenry and Wise, 1990). Job performance is of interest to organizations because of the importance of high productivity in the workplace (Hunter and Hunter, 1984). Performance definitions should focus on behaviors rather than outcomes because a focus on outcomes could lead employees to find the easiest way to achieve the desired results, which is likely to be detrimental to the organization because other important behaviors will not be performed (Murphy, 1989). Campbell, McCloy and Sager (1993) explained that performance is not the consequence of behaviors, but rather the behaviors themselves. In other words, the performance consists of the behaviors that employees actually engage in which can be observed.

Hypothesis 2: Workplace structure (support; supervisor support) positively relate to (a) job satisfaction and (b) commitment.

\section{Impact of Job Satisfaction and Commitment to Performance}

The relationship between job satisfaction and performance has been critically assessed in a variety of organizational settings. The results of these studies have been mixed. Cummings (1970) identified three major points of view concerning this relationship. Satisfaction causes performance, performance causes satisfaction and rewards cause both performance and satisfaction. All of these three views are supported by various researches. Mirvis and Lawer (1977) produced conclusive findings about the relationship between job satisfaction and performance. In attempting to measure the performance of bank tellers in terms of cash shortages, their proposed arguments are satisfied tellers were less likely to show shortages and less likely to leave their jobs. Kornhanuser and Sharp (1976) have conducted more than thirty studies to identify the relationship between satisfaction and performance in the industrial sector.

Many of the studies have found that a positive relationship existed between job satisfaction and performance. Katzell, Barret and Porker (1952) demonstrated that job satisfaction was associated neither with turnover nor with the quality of production. Smith and Cranny (1968) reviewed the literature and concluded that satisfaction is associated with performance as well as effort, commitment and intention.

In the western electric studies (1966) the evidence from the Relay Assembly test room showed a dramatic tendency for increased employee productivity to be associate of with an increase in job satisfaction. Porter and Lowler (1969) suggested that satisfaction will affect a worker's effort, arguing that increased satisfaction from performance 
possibility helps to increase expectations of performance leading to rewards, Carroll, Keflas and Watson (1964) found that satisfaction and productivity are crucial relationship in which each affects the other. They suggest that performance leads to more effort because of high perceived expectancy. The effort leads to effective performance, which again leads to satisfaction in crucial relationship. David, Joseph and William (1970) suggest that the type of reward system under which workers perform strongly influence the performance relationship (Pushpakumari, M. D. 2006.).

The literature review of the job performance indicated that depends on perception, values and attitudes (Pushpakumari, M. D. 2008). Many studies highlight different organizational determinants and examined their impact on Job performance, such as job satisfaction, rewards, training, wage growth, employees stress, and motivation and so on. Job performance is a core interest for any organization as it reflects the organizational productivity by reflecting the employees' ability to attain the goals as planned. In the study of Cook (2008), the researcher argued that the definition of the job performance should focus on the behavior, not the outcomes, because if the outcomes is the determinant of the job performance the employee may adopt the easiest way to get the job done regardless the quality of the methods and tools, on the other hand considering the job related behaviors will enhance the organizational ability to underline weaknesses and mistakes more effectively and accurately. The study indicated that job performance is not a consequence of behavior, it is a behavior itself. Borman, and Schmit (1997) defined job performance as behaviors with an evaluative aspect, cited by Cook, (2008), this definition indicated that job performance should be able to be measured in order to deliver the desired outcomes. Job performance was also defined as "a function of individual ability, skill and effort in a given situation (Porter and Lawler, 1974)" as cited by Pushpakumari (2008) (Talal T. Nusair, 2013).

Hypothesis 3: The (a) job satisfaction and (b) commitment positively relate to employee performance.

\section{REASEARCH METHODOLOGY}

\section{Data}

In this research, data is gathered through primary sources. The research methodology is the way to describe how the data are gathered and interpreted in order to meet the objective of the study. Generally, data can be obtained from primary sources. This study is mostly based on literature review and conceptual framework and developed 
hypotheses to examine the relationship between independent and dependent variables.

Data was analyzed using SmartPLS 2.0 to perform Partial Least Squares structural equation Modeling (SEM-PLS) to test the hypothesized relationship among the constructs in the proposed model depicted (see figure1). The SmartPLS 2.0 software was set to 500 bootstrap samples for the estimation of the significance of the t-values. Usually, the data analysis followed a two-step approach: estimation of the measurement model and the structural model.

\section{Sampling}

The population of this study is academic staff of public and private universities in Mongolia. The premium universities are in the public sector. These are the National University of Mongolia (NUM), the Mongolian University of Science and Technology (MUST), the Mongolian State University of Education (MSUE), the Health Sciences University of Mongolia (HSU) and the Mongolian State University of Agriculture (MSUA). Since the passage of the 1991 Education Law that established the legal basis for private universities and institutions, it has not been difficult to obtain a license to run a private college in Mongolia. All that was required was to have adequate facilities, a faculty, a library, and financial resources. With the increasing demand for tertiary education in the country and the fact that colleges do not pay value-added or profit taxes, investing in private colleges is lucrative. All regulatory and legislative norms apply to all educational institutions of whether public or private universities (The Asian Development Bank, 2004. "The Mongolian Education and Training Fund: Building a Sustainable Future." Draft).

This study developed a model of job satisfaction in the higher educational institutions (Figure 1) that embrace the theoretical and empirical work discussed above. This study proposed that job satisfaction is a determinant of effective performance dimensions and are most important and critical aspects of the work environment. If any organization has a positive job satisfaction then work outcome can be positive and performance higher. In this study, the concept was measured through Rokeach's (1973), instrument in his work on human employee training effectiveness values (Alexandros G. Sahinidis and John Bouris 2007). Cronbach's greater than 0.70 indicates that variable shows enough internal consistency (Kline, 2005; Talal T. Nusair, 2013).

\section{Characteristics of Sample}

Data was collected from Mongolian private, public universities as shown the model in Figure 1. The survey was conducted among Mongolian academic staff (professor, 
assistant professors, head of departments, and lecturer). Data was collected from October 2014 to February 2015. The selected public and private universities are a main research object of the study. Table 1 shows the results of respondents' characteristics. Among 160 public, academic staffs, 69 (43.0\%) were men, and 91 (57.0\%) were women. Among 143 private, academic staffs, 48 (33.6\%) were men, and 95 (66.4\%) were women. Respondents' characteristics are shown in Table 1.

Table 1 indicates the differences in demographics of respondents including gender, age, work experience, and position in public and private universities.

In terms of the academic staffs work experiences, table 1 displays that until 3 working years percentage is $16.3 \%(2.1 \%)$, and for $3-6$ years is $31.0 \%(37.8 \%)$ in public and

Table 1. Respondents' Characteristics

\begin{tabular}{|c|c|c|c|c|c|}
\hline \multirow{2}{*}{\multicolumn{2}{|c|}{ Respondents }} & \multicolumn{2}{|c|}{ Public University } & \multicolumn{2}{|c|}{ Private University } \\
\hline & & Frequency & Percent & Frequency & Percent \\
\hline \multirow{2}{*}{ Gender } & Male & 69 & 43.0 & 48 & 33.6 \\
\hline & Female & 91 & 57.0 & 95 & 66.4 \\
\hline \multicolumn{2}{|c|}{ Total (303) } & 160 & 100.0 & 143 & 100.0 \\
\hline \multirow{5}{*}{ Age } & $<24$ & 13 & 8.1 & 2 & 1.4 \\
\hline & $25-34$ & 42 & 26.3 & 34 & 23.8 \\
\hline & $35-44$ & 33 & 20.6 & 41 & 28.7 \\
\hline & $45-54$ & 39 & 24.4 & 42 & 29.4 \\
\hline & $55<$ & 33 & 20.6 & 24 & 16.8 \\
\hline \multicolumn{2}{|c|}{ Total (303) } & 160 & 100.0 & 143 & 100.0 \\
\hline \multirow{4}{*}{$\begin{array}{l}\text { Work experience } \\
\quad \text { (Years) }\end{array}$} & $<3$ years & 26 & 16.3 & 3 & 2.1 \\
\hline & $3-6$ years & 31 & 19.4 & 54 & 37.8 \\
\hline & $7-10$ years & 44 & 27.5 & 61 & 42.7 \\
\hline & 10 over years & 59 & 36.9 & 25 & 17.5 \\
\hline \multicolumn{2}{|c|}{ Total (303) } & 160 & 100.0 & 143 & 100.0 \\
\hline \multirow{4}{*}{ Position } & Professors & 3 & 1.9 & 7 & 4.9 \\
\hline & Assistant professors & 13 & 8.1 & 15 & 10.5 \\
\hline & Head of department & 21 & 13.1 & 37 & 25.9 \\
\hline & Lecturer & 123 & 76.9 & 84 & 58.7 \\
\hline \multicolumn{2}{|c|}{ Total (303) } & 160 & 100.0 & 160 & 100.0 \\
\hline
\end{tabular}


private university. For 7-10 years, and 10 over years, the valid percentage is $27.5 \%$ (42.7\%), and 36.9\% (17.5\%) respectively. The measures come from the existing scale, adapted to the theoretically based items thought survey with respondents. All measures used five-point Likert scales ("1= strongly disagree", and 5= "strongly agree"). It examined the validity of all items by confirmatory factor analysis via SmartPLS 2.0. See from the Appendix.

\section{Data Analysis: Assessment of Measurement Model}

In PLS, factor reliability was assessed by examining the loadings of the respective factors on their respective latent constructs (Hulland, 1999). In my study, all of item loadings represented high reliability. The factor loadings calculated by SmartPLS 2.0 are shown in Table 2 and Table 3.

Table 2. List of Items for Each Construct: Public University

\begin{tabular}{|c|c|c|c|c|c|c|}
\hline Constructs & Items & $\begin{array}{l}\text { Items } \\
\text { loading }\end{array}$ & T-value & $\begin{array}{l}\text { Cronbach's } \\
\text { alpha }\end{array}$ & $\mathrm{CR}$ & AVE \\
\hline \multirow{21}{*}{ OCTAPACE } & open1 & 0.692 & 8.256 & \multirow{21}{*}{0.950} & \multirow{21}{*}{0.955} & \multirow{21}{*}{0.712} \\
\hline & open2 & 0.633 & 10.243 & & & \\
\hline & conf1 & 0.787 & 19.791 & & & \\
\hline & conf2 & 0.776 & 13.676 & & & \\
\hline & conf3 & 0.679 & 11.644 & & & \\
\hline & trust1 & 0.786 & 20.649 & & & \\
\hline & trust2 & 0.809 & 16.488 & & & \\
\hline & trust3 & 0.710 & 12.548 & & & \\
\hline & trust4 & 0.767 & 13.512 & & & \\
\hline & auth1 & 0.800 & 15.737 & & & \\
\hline & auth2 & 0.701 & 7.893 & & & \\
\hline & auth3 & 0.655 & 11.181 & & & \\
\hline & proact1 & 0.700 & 9.556 & & & \\
\hline & proact2 & 0.655 & 7.505 & & & \\
\hline & auto1 & 0.686 & 13.305 & & & \\
\hline & auto2 & 0.685 & 11.382 & & & \\
\hline & collab1 & 0.789 & 20.922 & & & \\
\hline & collab2 & 0.709 & 13.113 & & & \\
\hline & collab3 & 0.687 & 15.835 & & & \\
\hline & exp1 & 0.778 & 16.636 & & & \\
\hline & exp2 & 0.648 & 7.831 & & & \\
\hline
\end{tabular}




\begin{tabular}{|c|c|c|c|c|c|c|}
\hline Constructs & Items & $\begin{array}{l}\text { Items } \\
\text { loading }\end{array}$ & T-value & $\begin{array}{l}\text { Cronbach's } \\
\text { alpha }\end{array}$ & CR & AVE \\
\hline \multirow{4}{*}{$\begin{array}{l}\text { WORKPLACE } \\
\text { STRUCTURE }\end{array}$} & sup1 & 0.758 & 15.519 & \multirow{4}{*}{0.754} & \multirow{4}{*}{0.844} & \multirow{4}{*}{0.758} \\
\hline & sup2 & 0.740 & 10.052 & & & \\
\hline & super1 & 0.810 & 21.432 & & & \\
\hline & super2 & 0.720 & 11.810 & & & \\
\hline \multirow{4}{*}{ JOB SATISFACTION } & sat1 & 0.716 & 10.690 & \multirow{4}{*}{0.801} & \multirow{4}{*}{0.867} & \multirow{4}{*}{0.788} \\
\hline & sat2 & 0.843 & 30.104 & & & \\
\hline & sat3 & 0.798 & 19.306 & & & \\
\hline & sat4 & 0.790 & 18.572 & & & \\
\hline \multirow{4}{*}{$\begin{array}{l}\text { ORGANIZATONAL } \\
\text { COMMITMENT }\end{array}$} & com1 & 0.783 & 25.692 & \multirow{4}{*}{0.723} & \multirow{4}{*}{0.827} & \multirow{4}{*}{0.738} \\
\hline & com2 & 0.731 & 11.913 & & & \\
\hline & com3 & 0.700 & 11.211 & & & \\
\hline & com4 & 0.739 & 11.499 & & & \\
\hline \multirow{3}{*}{$\begin{array}{l}\text { EFFECTIVE } \\
\text { PERFORMANCE }\end{array}$} & per1 & 0.910 & 51.911 & \multirow{3}{*}{0.847} & \multirow{3}{*}{0.907} & \multirow{3}{*}{0.875} \\
\hline & per2 & 0.860 & 21.238 & & & \\
\hline & per3 & 0.854 & 24.648 & & & \\
\hline
\end{tabular}

Note: All items were measured on a 5 point scale, All items were anchored with 1= "strongly disagree" / 5 = "strongly agree"

Table 3. List of Items for Each Construct: Private University

\begin{tabular}{|c|c|c|c|c|c|c|}
\hline Constructs & Items & $\begin{array}{l}\text { Items } \\
\text { loading }\end{array}$ & T-value & $\begin{array}{l}\text { Cronbach's } \\
\text { alpha }\end{array}$ & CR & AVE \\
\hline \multirow{10}{*}{ OCTAPACE } & open1 & 0.771 & 14.221 & \multirow{10}{*}{0.973} & \multirow{10}{*}{0.975} & \multirow{10}{*}{0.667} \\
\hline & open2 & 0.801 & 14.712 & & & \\
\hline & collab1 & 0.803 & 20.291 & & & \\
\hline & collab2 & 0.802 & 22.181 & & & \\
\hline & trust1 & 0.880 & 18.781 & & & \\
\hline & trust2 & 0.817 & 23.539 & & & \\
\hline & trust3 & 0.857 & 18.742 & & & \\
\hline & auth1 & 0.735 & 13.809 & & & \\
\hline & auth2 & 0.869 & 23.388 & & & \\
\hline & auth3 & 0.774 & 19.853 & & & \\
\hline
\end{tabular}




\begin{tabular}{|c|c|c|c|c|c|c|}
\hline Constructs & Items & $\begin{array}{l}\text { Items } \\
\text { loading }\end{array}$ & T-value & $\begin{array}{l}\text { Cronbach's } \\
\text { alpha }\end{array}$ & CR & AVE \\
\hline \multirow{10}{*}{ OCTAPACE } & proact1 & 0.774 & 22.095 & \multirow{10}{*}{0.973} & \multirow{10}{*}{0.975} & \multirow{10}{*}{0.667} \\
\hline & proact2 & 0.857 & 19.369 & & & \\
\hline & auto1 & 0.829 & 22.485 & & & \\
\hline & auto2 & 0.845 & 18.473 & & & \\
\hline & conf1 & 0.870 & 25.347 & & & \\
\hline & conf2 & 0.782 & 21.074 & & & \\
\hline & conf3 & 0.805 & 20.403 & & & \\
\hline & exp1 & 0.890 & 19.806 & & & \\
\hline & $\operatorname{exp2}$ & 0.755 & 20.979 & & & \\
\hline & $\operatorname{exp3}$ & 0.883 & 18.741 & & & \\
\hline \multirow{4}{*}{$\begin{array}{l}\text { WORKPLACE } \\
\text { STRUCTURE }\end{array}$} & sup1 & 0.796 & 4.0776 & \multirow{4}{*}{0.868} & \multirow{4}{*}{0.897} & \multirow{4}{*}{0.687} \\
\hline & sup2 & 0.852 & 4.686 & & & \\
\hline & super1 & 0.829 & 3.620 & & & \\
\hline & super2 & 0.837 & 4.630 & & & \\
\hline \multirow{4}{*}{ JOB SATISFACTION } & sat1 & 0.865 & 21.981 & \multirow{4}{*}{0.898} & \multirow{4}{*}{0.929} & \multirow{4}{*}{0.768} \\
\hline & sat2 & 0.893 & 22.364 & & & \\
\hline & sat3 & 0.921 & 20.546 & & & \\
\hline & sat4 & 0.823 & 20.539 & & & \\
\hline \multirow{4}{*}{$\begin{array}{l}\text { ORGANIZATONAL } \\
\text { COMMITMENT }\end{array}$} & com1 & 0.934 & 31.286 & \multirow{4}{*}{0.940} & \multirow{4}{*}{0.957} & \multirow{4}{*}{0.848} \\
\hline & com2 & 0.946 & 31.752 & & & \\
\hline & com3 & 0.915 & 39.490 & & & \\
\hline & com4 & 0.885 & 31.437 & & & \\
\hline \multirow{3}{*}{$\begin{array}{l}\text { EFFECTIVE } \\
\text { PERFORMANCE }\end{array}$} & per1 & 0.920 & 26.317 & \multirow{3}{*}{0.885} & \multirow{3}{*}{0.929} & \multirow{3}{*}{0.814} \\
\hline & per2 & 0.926 & 18.649 & & & \\
\hline & per3 & 0.858 & 18.904 & & & \\
\hline
\end{tabular}

Note: All items were measured on a 5 point scale, All items were anchored with 1 = "strongly disagree" / 5 = "strongly agree"

Construct reliability measures the extent of internal consistency of measures used, and it is assessed through Cronbach's alpha with the acceptable level of 0.7 for basic research and also through composite reliability, with acceptable values of 0.70 (Hair et al, 2010). From Table 2, all of the constructs have higher Cronbach alphas above 0.70, 
indicating that these multiple measures are highly reliable for the measurement of each construct. Construct validity assesses the degree to which a measurement represents and logically connects the observed phenomenon to the construct through the fundamental theory (Fornell and Larcker, 1981). It is assessed through convergent validity and discriminant validity (Hair et al, 2010). Convergent validity can be assessed through construct factor (item) loadings (or cross loadings in PLS), the average variance extracted (AVEs) that should have minimum loading of 0.5 , and composite reliability (CR) with an acceptable minimum of 0.70 (Hair et al, 2010). From Table 2, the factor loadings of items to their respective constructs are stronger than they load on other constructs providing evidence in support of the convergent validity of the derived measures. Moreover, the CR values for all constructs range from 0.827 to 0.955 setting the acceptable requirement of 0.70 confirming the convergent validity of the measurement (outer) model. Discriminant validity was considered adequate since the AVEs are greater than their respective inter-construct correlations as is in Table 2 (Fornell and Larcker, 1981). Given that construct reliability and validity conditions of the measurement model are acceptable.

Table 4. Latent Variable Correlations (Public University)

\begin{tabular}{l|c|c|c|c|c}
\hline & OCTAPACE & $\begin{array}{c}\text { Workplace } \\
\text { structure }\end{array}$ & $\begin{array}{c}\text { Job } \\
\text { satisfaction }\end{array}$ & Commitment & Performance \\
\hline OCTAPACE & 1.000 & & & & \\
\hline Workplace structure & $0.679^{\star *}$ & 1.000 & & & \\
\hline Job satisfaction & $0.615^{\star \star}$ & 0.337 & 1.000 & & \\
\hline Commitment & $0.767^{\star *}$ & $0.637^{\star *}$ & 0.382 & 1.000 & \\
\hline Performance & $0.487^{\star *}$ & 0.289 & $0.653^{\star *}$ & $0.568^{\star *}$ & 1.000 \\
\hline
\end{tabular}

${ }^{* *}$ Correlation is significant at the 0.01 level (2-tailed).

Table 5. Latent Variable Correlations (Private University)

\begin{tabular}{l|c|c|c|l|c}
\hline & Commitment & $\begin{array}{c}\text { Job } \\
\text { Satisfaction }\end{array}$ & OCTAPACE & Performance & $\begin{array}{c}\text { Workplace } \\
\text { structure }\end{array}$ \\
\hline Commitment & 1.000 & & & & \\
\hline Job Satisfaction & $0.708^{\star *}$ & 1.000 & & & \\
\hline OCTAPACE & $0.917^{\star *}$ & $0.891^{\star *}$ & 1.000 & & \\
\hline Performance & $0.854^{\star *}$ & $0.712^{\star *}$ & $0.862^{\star *}$ & 1.000 & \\
\hline Workplace structure & $0.536^{\star *}$ & 0.368 & $0.537^{\star *}$ & $0.639^{\star *}$ & 1.000 \\
\hline
\end{tabular}

${ }^{* *}$ Correlation is significant at the 0.01 level (2-tailed). 
All in public and private university variables are significantly related to each other's. In public university OCTAPACE and job satisfaction is highly correlated $(\mathrm{r}=0.615)$ and OCTAPACE and commitment also significantly correlated $(\mathrm{r}=0.767)$. In private university, all main variables are positively correlated for instance: commitment and job satisfaction is high significant $(\mathrm{r}=0.917)$.

\section{Results of Structural Model}

In PLS-SEM, structural model's validity are assessed through the strength of regression weights, $t$-values, $\mathrm{p}$-values for significance of t-statistics, as well as effect sizes of independent variables on the dependent variables.

The results from Table 6 and Table 7 show that hypotheses 1 (Organizational cultures (OCTAPACE) are (Openness, Confrontation; Trust; Authenticity; Pro-Action; Autonomy; Collaboration; Experimentation) positively relate to (a) job satisfaction and (b) organizational commitment) and hypotheses 3 (The (a) job satisfaction and (b) commitment positively relate to employee performance) were supported in according

Figure 2. Results of Hypothesis Testing (Public University)

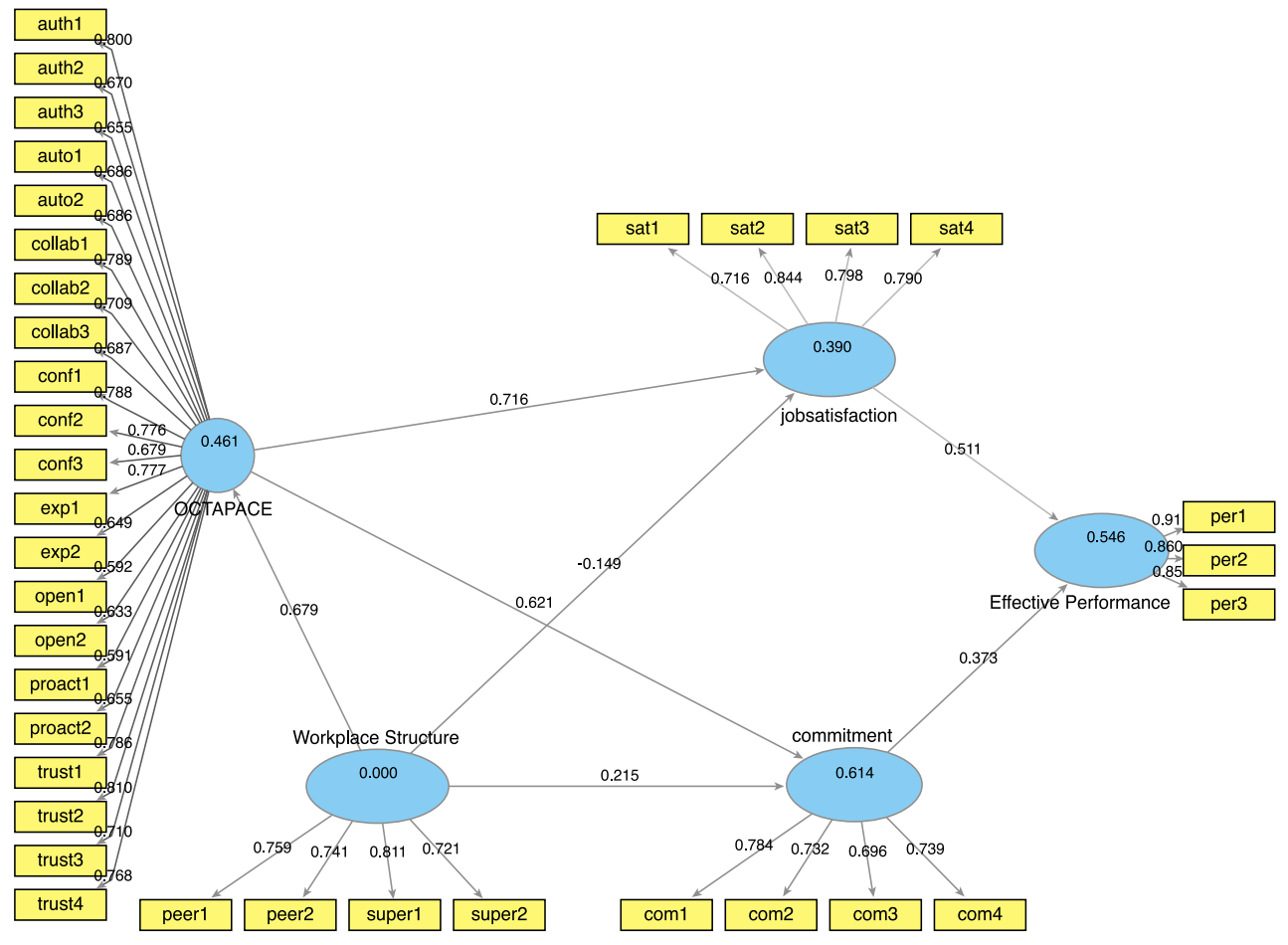


Figure 3. Results of Hypothesis Testing (Private University)

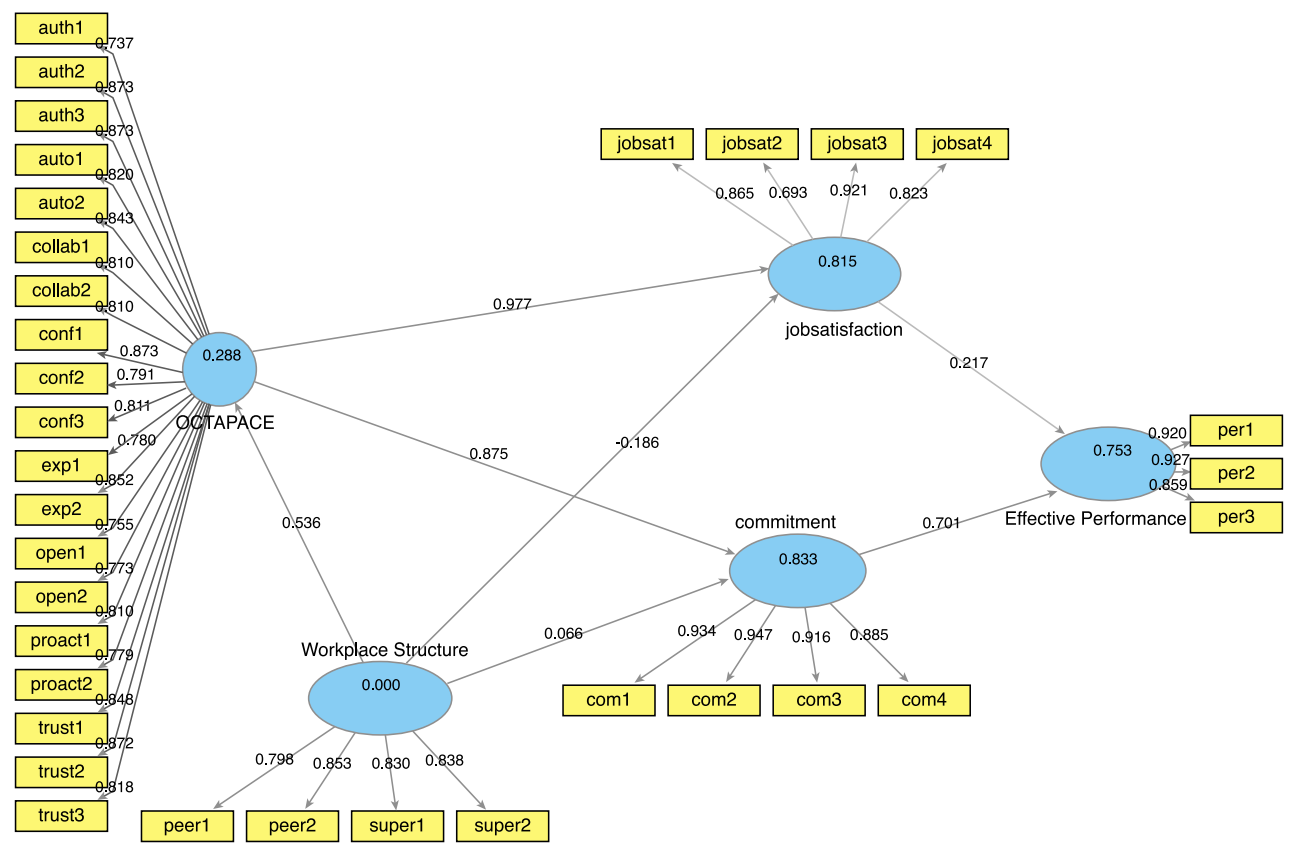

to data. But the expected results show that hypotheses 2a (Workplace structure (support; supervisor support) positively relate to (a) job satisfaction) was mostly supported in according to given data. In public university, I examined the structural path model to test the hypothesis has shown in figure 1.

In public university, the relationship of the OCTAPACE between job satisfaction was significant $(\beta=0.716, t=7.157)$, and organizational commitment was significant $(\beta=0.621, t=10.750)$. Thus, workplace structure significant influence on organizational commitment $(\beta=0.216, t=3.208)$ but insignificant influence on job satisfaction $(\beta=$ $-0.149, \mathrm{t}=1.523)$.

Specifically, it indicates that the job satisfaction $(\mathrm{H} 3 \mathrm{a})(\beta=0.511, \mathrm{t}=6.535)$ and organizational commitment $(\mathrm{H} 3 \mathrm{~b})(\beta=0.373 \mathrm{t}=4.224)$ was significantly influenced on effective job performance (Figure 2).

In private university, I examined the structural path model to test the hypothesis by figure 1 .

In private university, the relationship of the OCTAPACE between job satisfaction was significant $(\beta=0.977, t=27.571)$, and organizational commitment was significant $(\beta=0.876, t=23.208)$. Thus, workplace structure insignificant influence on organizational commitment $(\beta=0.066, t=1.055)$, negative influence on job satisfaction $(\beta=-$ 
0.156, $\mathrm{t}=2.60)$ and significant influence on OCTAPACE $(\beta=0.536, t=8.532)$. Specifically, it indicated that the job satisfaction $(\mathrm{H} 3 \mathrm{a})(\beta=0.217, \mathrm{t}=2.882)$ and organizational commitment $(\mathrm{H} 3 \mathrm{~b})(\beta=0.700 \mathrm{t}=11.283)$ was significantly influenced on effective job performance (Figure 3 ).

In table 6, Mongolian public universities data result indicates the hypothesis was significantly supported. However, workplace structure that support and supervisor support negatively influence to organizational commitment.

In table 7, Mongolian private universities data result indicates the hypothesis was

Table 6. Results of Hypothesis Testing (Public University)

\begin{tabular}{c|l|c|r|r|r|l}
\hline Hypothesis & Path & $\begin{array}{c}\text { Regression } \\
\text { weight }\end{array}$ & $\begin{array}{c}\text { Standard } \\
\text { Error }\end{array}$ & T Statistic & P-value & Remarks \\
\hline $\mathrm{H} 1 \mathrm{a}$ & Octa $\rightarrow$ JoSat & 0.716 & 0.100 & 7.157 & 0.000 & Supported \\
\hline $\mathrm{H} 1 \mathrm{~b}$ & Octa $\rightarrow$ OrCom & 0.621 & 0.057 & 10.750 & 0.000 & Supported \\
\hline $\mathrm{H} 2 \mathrm{a}$ & WoSt $\rightarrow$ JoSat & -0.149 & 0.090 & 1.523 & 0.127 & $\begin{array}{c}\text { Not } \\
\text { Supported }\end{array}$ \\
\hline $\mathrm{H} 2 \mathrm{~b}$ & WoSt $\rightarrow$ OrCom & 0.216 & 0.065 & 3.280 & 0.000 & Supported \\
\hline $\mathrm{H} 2 \mathrm{c}$ & WoSt $\rightarrow$ Octa & 0.679 & 0.049 & 13.801 & 0.000 & Supported \\
\hline $\mathrm{H} 3 \mathrm{a}$ & JoSat $\rightarrow$ EfPer & 0.511 & 0.078 & 6.535 & 0.000 & Supported \\
\hline $\mathrm{H} 3 \mathrm{~b}$ & OrCom $\rightarrow$ EfPer & 0.373 & 0.088 & 4.224 & 0.000 & Supported \\
\hline
\end{tabular}

Note: Octa-OCTAPACE, JoSat-job satisfaction, WoSt-workplace structure, EfPer-effective performance, OrCom-organizational commitment.

Table 7. Results of Hypothesis Testing (Private University)

\begin{tabular}{c|l|c|c|c|c|c}
\hline Hypothesis & Path & $\begin{array}{c}\text { Regression } \\
\text { weight }\end{array}$ & $\begin{array}{c}\text { Standard } \\
\text { Error }\end{array}$ & T Statistic & P-value & Remarks \\
\hline $\mathrm{H} 1 \mathrm{a}$ & Octa $\rightarrow$ JoSat & 0.977 & 0.035 & 27.576 & 0.000 & Supported \\
\hline $\mathrm{H} 1 \mathrm{~b}$ & Octa $\rightarrow$ OrCom & 0.875 & 0.038 & 23.208 & 0.000 & Supported \\
\hline $\mathrm{H} 2 \mathrm{a}$ & WoSt $\rightarrow$ JoSat & -0.156 & 0.0592 & 2.609 & & Supported \\
\hline $\mathrm{H} 2 \mathrm{~b}$ & WoSt $\rightarrow$ OrCom & 0.066 & 0.052 & 1.055 & & $\begin{array}{c}\text { Not } \\
\text { Supported }\end{array}$ \\
\hline $\mathrm{H} 2 \mathrm{c}$ & WoSt $\rightarrow$ Octa & 0.536 & 0.063 & 8.532 & 0.000 & Supported \\
\hline $\mathrm{H} 3 \mathrm{a}$ & JoSat $\rightarrow$ EfPer & 0.217 & 0.075 & 2.882 & 0.000 & Supported \\
\hline $\mathrm{H} 3 \mathrm{~b}$ & OrCom $\rightarrow$ EfPer & 0.701 & 0.062 & 11.283 & 0.000 & Supported \\
\hline
\end{tabular}

Note: Octa-OCTAPACE, JoSat-job satisfaction, WoSt-workplace structure, EfPer-effective performance, OrCom-organizational commitment. 
significantly supported but path coefficient from the workplace structure to organizational commitment was not significant.

\section{Mediation Analysis}

This study examined the models of mediation effects. Therefore, the mediator variable indicates the nature of the relationship between the independent and dependent variables. The results of this analysis, the variables that job satisfaction, organizational commitment and OCTAPACE are mediated relationship between OCTAPACE and effective performance and relationship between workplace structure and effective performance. For instance, in public university, the job satisfaction mediated the relationship between OCTAPACE and effective performance $(\mathrm{z}=5.45)$ and the organizational commitment mediated the relationship between OCTAPACE and effective performance mediation effects of job satisfaction $(\mathrm{z}=4.717)$ Therefore, in private universities, the job satisfaction mediated the relationship between workplace structure and effective performance $(\mathrm{z}=7.201)$. As the data has reliable and valid outer model estimation, and then that can evaluated the inner model.

The R-Square measures the predictive power of the structural model in PLS analysis. The predictive power of each independent variable and their respective dependent variables were conducted by eliminating each of the dependent variable in question, one at a time in an iterative process. The effect size is estimated as shown in table 8.

This implies that all the dependent variables (OCTAPACE, workplace structure, job satisfaction, and organizational commitment) are collectively predict intentions and adopt significantly. In public university, the predictive power of the other dependent variables, job satisfaction $\left(R^{2}=0.390\right)$, organizational commitment $\left(R^{2}=0.614\right)$, OCTAPACE $\left(\mathrm{R}^{2}=0.461\right)$ and effective performance $\left(\mathrm{R}^{2}=0.546\right)$ also suggests significant effect sizes. In private university, the predictive power of the other dependent variables, job satisfaction $\left(\mathrm{R}^{2}=0.799\right)$, organizational commitment $\left(\mathrm{R}^{2}=0.833\right)$, OCTAPACE $\left(\mathrm{R}^{2}=0.288\right)$ and effective performance $\left(\mathrm{R}^{2}=0.753\right)$ also suggests significant effect

Table 8. Evaluation of Structural Model

\begin{tabular}{c|c|c}
\hline Criterion & \multicolumn{1}{|c|}{ Limitation of value } & Interpretation \\
\hline \multirow{2}{*}{$\mathrm{R}^{2}$} & $>0.67$ Substantial & $\mathrm{R}^{2}$ of endogenous latent variable \\
& $>0.33$ Moderate & \\
& $>0.19$ Weak & $\mathrm{f}^{2}=\left(\mathrm{R}^{2}\right.$ included $-\mathrm{R}^{2}$ excluded $) /\left(1-\mathrm{R}^{2}\right.$ included $)$ \\
Effect size $\mathrm{f}^{2}$ & $>0.02$ Weak & $>0.15$ Medium \\
& $>0.35$ Large & (Cohen, 1988) \\
\hline
\end{tabular}


Table 9. Results of Mediation Analysis

\begin{tabular}{l|c|c|c|c|c|c}
\hline \multirow{2}{*}{ Path } & \multicolumn{2}{|c|}{ Indirect Effect } & \multicolumn{2}{c|}{ Sobel test } & \multicolumn{2}{c}{$f$} \\
\cline { 2 - 7 } & Public & Private & Public & Private & Public & Private \\
\hline Octa $\rightarrow$ JoSat $\rightarrow$ EfPer & 0.345 & -0.264 & 5.45 & -2.046 & 0.182 & 0.023 \\
\hline Octa $\rightarrow$ OrCom $\rightarrow$ EfPer & 0.379 & 0.331 & 4.717 & 7.505 & 0.007 & 0.080 \\
\hline WoSt $\rightarrow$ JoSat $\rightarrow$ EfPer & 0.233 & 0.374 & 4.425 & 7.201 & 0.527 & 0.066 \\
\hline WoSt $\rightarrow$ OrCom $\rightarrow$ EfPer & 0.420 & 0.196 & 7.180 & 3.807 & 0.283 & 0.082 \\
\hline WoSt $\rightarrow$ Octa $\rightarrow$ JoSat & 0.478 & 0.524 & 6.746 & 8.240 & 0.356 & 0.156 \\
\hline
\end{tabular}

Note: Octa-OCTAPACE, JoSat-job satisfaction, WoSt-workplace structure, EfPer-effective performance, OrCom-organizational commitment.

sizes. The Sobel test has been used for this study too. In terms of Sobel test, the result was as significance of mediation effects. Results are shown in Table 9. In according to table 9 , the model indicates a whole prediction was about $50.0 \%$ to job effective performance, which indicates a good effect size. Results are shown in Table 9.

\section{DISCUSSION}

In this study, I found that each finding of OCTAPACE, workplace structure, organizational commitment and job satisfaction has a different impact on the different dimensions of job satisfaction and effective performance. Those of above mentioned findings represent one of the most complex issues have been faced in Mongolia today. Although thousands of papers and research have been conducted on job satisfaction all over the world but for in Mongolian context this subject of study is one of the least studied research fields. Therefore, I highly considered the OCTAPACE is a suitable model in Mongolian context. This study result has indicated the importance of further deep study on job satisfaction and effective performance in Mongolia. My study investigated the roles of employee job satisfaction and an organizational commitment to the effective job performance and also it examined the requirements of job satisfaction and commitment. In addition, this study conducted simple comparison survey between public and private universities. The survey result has shown as follow:

In public university', the relationship of the OCTAPACE and job satisfaction was significant, and organizational commitment was significant too. Therefore, workplace structure significant influence on organizational commitment but insignificant influence on job satisfaction. For instance, the job satisfaction and organizational commitment 
was significantly influenced on effective job performance.

For private university', the relationship of the OCTAPACE and job satisfaction was significant, and organizational commitment was significant too. Therefore, workplace structure insignificant influence on organizational commitment, negative influence on job satisfaction and significant influence on OCTAPACE. The job satisfaction and organizational commitment was significantly influenced on effective job performance as well as public university'.

In table 6, Mongolian public universities data result indicates the hypothesis 1 and hypotheses 3 was significantly supported. However, hypothesis 3 workplace structure and organizational commitment interrelation was negative result. In private university, hypothesis 1 and hypotheses 3 was significantly supported, but path coefficient from the workplace structure to organizational commitment was not significant.

In addition, this study tried to find that OCTAPACE, job satisfaction, workplace structure and organizational commitment influenced on effective performance but workplace structure and job satisfaction interrelation was negative or not supportive. Therefore, my study suggested that eight dimensions of OCTAPACE culture can build high job satisfaction and commitment for university employees.

\section{CONCLUSION}

The findings of this study have implications for public and private universities as well as other universities in Mongolia. In Mongolia has 17 public and 94 private universities estimated from Mongolian national statistic of 2014. In Mongolian higher educational institutions, the situations in other universities are not very different from the public and private universities. Mongolian university administration activity required to renew or reach at globalized university contexts.

Job satisfaction itself directly relates with human resource management. Thus, it tells that whole education system needs to make fundamental changes in policy level as well as in field. Based on these considerations, staff hiring, training, and evaluation and reward systems might need to be rethink over the long term. In addition, the unexplained variances in this model could be explained by adding other factors such as Mongolian socio-economic issues, political situations and lower developing country context. Therefore, I recommend in Mongolia need to more pay attention on human resource management and development. In according to this recommendation, I suggest that Mongolian government need to make long term concrete strategy, implement it step by step and frequency monitoring. Moreover, institutional leaders and policy makers are encouraged to train, gain experiences and enhance their skills on work place. 


\section{REFERENCE}

Akfopure, R. R., Ikhifa, O. G., Imide, O. I., \& Okokoyo I. E. 2006. Job satisfaction among educators in colleges of education in Southern Nigeria. Journal of Applied Sciences, 6(5): 994-1098.

Austin, A. E., \& Gamson, Z. F. 1983. Academic workplace: New demands, heightened tensions. ASHE-ERIC Washington University. Higher Education Report No. 10.

Baker, K. A. 2002. Chapter 11. Organizational culture, cited bty 40-Related articles www.au.af.mil/au/awc/awcgate/benchmark/ch11.pdf.

Baron, R. M., \& Kenny, D. A. 1986. The moderator-mediator variable distinction in social psychological research: Conceptual, strategic, and statistical considerations. Journal of Personality and Social Psychology, 51: 1173-1182.

Bateman, T. S., \& Strasser, S. 1984. A longitudinal analysis of the antecedents of organizational commitment. Academy of Management Journal, 27: 95-112.

Bozeman, B., \& M. Gaughan. 2011. Job satisfaction among university faculty: Individual, work, and institutional determinants. The Journal of Higher Education, 82(2): 154-86.

Bruce, W. M., \& Blackburn, J. W. 1992. Balancing job satisfaction and performance. Westport, CT: Quorum Books.

Burke, R. J. 1988. Sources of managerial and professional stress in large organizations. In C. L. Cooper \& R. Payne (eds.), Causes, coping and consequences of stress at work (pp. 77-114). New York \& Chichester: John Wiley \& Sons.

Campbell, J. P., McHenry, J. J., \& Wise, L. L. 1990. Modeling job performance in a population of jobs. Personnel Psychology, 43: 313-333

Charles H. Schwepker Jr. 2001. Ethical climate's relationship to job satisfaction, organizational commitment, and turnover intention in the sales force. Journal of Business Research, 54.

Chen, Z. X., \& Francesco, A. M. 2000. Employee demography, organizational commitment, and turnover intentions in China: Do cultural differences matter? Human Relations, 3(6): 869-878.

Currivan D. B. 1999. The causal order of job satisfaction and organizational commitment in models of employee turnover. Human Resource Management Review, (4): 10534822.

Davies N., Michael J., \& Classen A. J. 2008. Impact of organizational changeon organizational culture, implications for introducing evidence based practice. Journal of Evidence-Based Social Work, 5: 321-359.

Iverson, R. D. 1992. Employee intent to stay: An empirical test of a revision of the price and mueller model. Iowa City, IA: The University of Iowa (unpublished 
doctoral dissertation).

Getahun, S. B., \& Hummer, S. D. 2008. Job satisfaction and organizational commitment among probation and parole officers: A case study. A Professional Journal, $3(1)$.

Glisson. C., \& Durick, M. 1988. Predictors of job satisfaction and organizational commitment in human service organizations. Administrative Science Quarterly, 33(1): 61-81.

Glick, L. N. 1992. Job satisfaction among academic administrators. Research in Higher Education, 33(5): 625-639.

Greg L. Stewart, \& Kenneth G. Brown. 2011. Human resource management (2nd edition), John Wiley \& Sons, Inc. ISBN-139780470530498, Chapter 9.

Hair, J. F., Black, W. C., Babin, B. J., \& Anderson, R. E. 2010. Multivariate data analysis. Englewood Cliffs, NJ: Prentice Hall.

Herzberg, F., Mausner, B., \& Snyderman, B. 1959. The motivation to work. New York, NY: John Wiley.

Hoppock, R. 1977. Job satisfaction. New York: Anno Press.

Hussin. B. A. 2011 The relationship between job satisfaction and job performance among employees in trade winds group of companies. Centre for Graduate studies, University Malaysia.

John C. Weidman, \& Brian Yoder. 2010. Policy and practice in education reform in Mongolia and Uzbekistan during the first two decades of the Post-Soviet era. Excellence in Higher Education, 1: 57-68.

Judge, T. A., Thoresen, C. J., Bono, J. E., \& Patton, G. K. 2001. The job satisfactionrelationship: A qualitative and quantitative review. Psychological Bulletin, 127(3): 36-40.

Kalleberg, A. L. 1977. Work values and job rewards: A theory of job satisfaction. American Sociological Review, 42: 124-143.

Lambert, E. G. 2004. Organizational citizenship behavior and commitment among correstional staff. Criminal justice and behavior, 35(1).

Lau, C. M., \& Chong, J. 2002. The effects of budget emphasis, participation and organizational commitment on job satisfaction: Evidence from the financial services sector. Advances in Accounting Behavioral Research, 5: 183-211.

Lawler, E. J. 1992. Affective attachments to nested groups: A choice-process theory. American Sociological Review, 57: 327-339.

Locke, E. A. 1970. Job satisfaction and job performance: A theoretical analysis. Organizational Behavior and Human Performance, 5(b): 484-500.

Locke, E. A. 1976. The nature and causes of job satisfaction. In M. D. Dunnette (ed.), Handbook of industrial and organizational psychology (pp. 1297-1349). Chicago: 
Rand McNally.

Maslow, A. H. 1970. Motivation and personality. New York: Harper \& Row.

Mathieu, J. E., \& Farr, J. L. 1991. Further evidence for the discriminant validity of measures of organizational commitment, job involvement, and job satisfaction. Journal of Applied Psychology, 76: 127-133.

Mohammad, Hassan Jafri. 2012. An empirical study of OCTAPACE culture and organizational commitment, Vol. 1, No. 2, October-December' 2012 ISSN (P):22790934, (O):2279-0942.

Mowday, R., Porter, L., \& Steers, R. 1982. Employee-organization linkages: The psychology of commitment, absenteeism, and turnover. New York: Academic Press.

Murphy, M. K., Shleifer. A., \& Vishny, R. W. 1989. Industralization and big push. The Journal of Polictical Ecoomy, 97(5): 1003-1026.

Norizan, Ismail. 2012. Organizational commitment and job satisfaction among staff of higher learning education institutions in Kelantan, from https://www.google. co.kr.

Ozer, D. J., \& Benet-Martinez, V. 2006. Personality and the prediction of consequential outcomes. Annual Review of Psychology, 57: 401-421.

Peters, T. J., \& Waterman, R. H. Jr. 1982. In search of excellence: Lessons from America's best-run companies. New York: Harper \& Row Publishers.

Pushpakumari, M. D. 2008. The impact of job satisfaction on job performance: An empirical analysis. City Forum, 89-105.

Rao, T. V. 1990. The HRD missionary role and functions of HRD managers and HRD departments. Oxford \& IBH Publishing Co. (Pvt.) Ltd., New Delhi.

Rokeach M. 1979. The two-value model of political ideology and british politics. British Journal Social and Clinical Psychology, 18: 169-172.

Rees, D. W. 1995. Workrelated stress in health service employees. Journal of Managerial Psychology, 10(3): 4-11.

Saari, L. M., \& Judge, T. A. 2004. Employee attitudes and job satisfaction. Human Resource Management, 43: 395-407.

Satoko, Yano. 2012. Overeducated? The impact of higher education expansion in posttransition Mongolia. https://academiccommons.columbia.edu/.../Yano_columbia _0054D_106.

Schein, E. H. 1991. What is culture? In P. J. Frost, L. F. Moore, M. R. Louis, C. C. Lundberg, \& J. Martin, Reframing organizational culture (pp. 243-253). Newbury Park, CA: Sage.

Smith, P. C., Kendall, L. M., \& Hulin, C. L. 1969. The measurement of satisfaction in work and retirement. Chicago: Rand McNally. 
Spector, P. E. 1997. Job satisfaction: Application, assessment, cause and consequences. Thousand Oaks, CA: http://books.google.com/books?id=nCkXMZjs0XcC\& printsec.

Stephen P. Robbins, \& Mary Coutler. 2009. Management (10th edition), Pearson Education, Inc., Upper Saddle River, New Jersey, 07458. Chapter 3, Chapter 9.

Subrahmanian, Mu. 2012. Achieving high involvement and satisfaction through OCTAPACE culture in IT companies. International Journal of Business Economics \& Management Research, 2(5).

Udai P., \& Rao T. V. 1992. Designing and managing human resource systems (2nd Edition). New Delhi: Oxford \& IBH, 412p.

Vathanophas, V., \& J. Thai-ngam. 2007. Competency requirements for effective job performance in the Thai public sector. Contemporary Management Research, 3(1): 45-70.

Voon M. L., Lo M. C., Ngui K. S., \& Ayob N. B. 2011. The influence of leadership styles on employees' job satisfaction in public sector organizations in Malaysia. International Journal of Business, Management and Social Sciences, 2(1): 24-32.

Volkwein, J. F., S. M. Malik, \& M. Napierski-Prancl. 1998. Administrative satisfaction and the regulatory climate at public universities. Research in Higher Education, 39(1): 43-63.

Yafang, Tsai. 2011. Relationship between organizational culture, leadership behavior and job satisfaction, http://www.biomedcentral.com/1472-6963/11/98.

Young, K. M., \& Cooper, C. L. 1995. Occupational stress in the ambulance service: A diagnostic study. Journal of Managerial Psychology, 10(3): 29-36. 


\section{APPENDIX}

All Measures used Five-point Likert Scales (" $1=$ strongly disagree", and $5=$ "strongly agree").

\begin{tabular}{|c|c|c|c|c|c|c|c|c|}
\hline \multirow{2}{*}{\multicolumn{3}{|c|}{ Construct/ Indicators }} & \multicolumn{5}{|c|}{ scale } & \multirow{2}{*}{ Origin } \\
\hline & & & 1 & 2 & 3 & 4 & 5 & \\
\hline \multicolumn{9}{|l|}{ OCTAPACE } \\
\hline \multirow{3}{*}{ Openness } & Open 1 & \begin{tabular}{|l|} 
Free interaction \\
amongst employees, \\
each respecting other's \\
feelings, competence \\
and sense of judgment
\end{tabular} & & & & & & \multirow{12}{*}{$\begin{array}{l}\text { Cameron, Quinn (1999) } \\
\text { Davies, Nutley, et al ( 2008) } \\
\text { Locke (1976) } \\
\text { Norizan Ismail ( 2012) } \\
\text { Pushpakumari. M. D (2006) } \\
\text { Subranmanian (2012) } \\
\text { Schein(1990) } \\
\text { Rao, Abraham (1986) } \\
\text { Robbins, Judge (2009) } \\
\text { Udai Pareek (1992) }\end{array}$} \\
\hline & Open 2 & $\begin{array}{l}\text { Genuine sharing of } \\
\text { information, feelings, } \\
\text { and thoughts in } \\
\text { meetings }\end{array}$ & & & & & & \\
\hline & Open 3 & $\begin{array}{l}\text { Free discussion and } \\
\text { communication } \\
\text { between seniors and } \\
\text { subordinates. }\end{array}$ & & & & & & \\
\hline \multirow{3}{*}{ Collaboration } & Collab 1 & $\begin{array}{l}\text { Team work and team } \\
\text { spirit. }\end{array}$ & & & & & & \\
\hline & Collab 2 & $\begin{array}{l}\text { Accepting and } \\
\text { appreciating help } \\
\text { offered by others. }\end{array}$ & & & & & & \\
\hline & Collab 3 & $\begin{array}{l}\text { Performing immediate } \\
\text { tasks rather than being } \\
\text { concerned about large } \\
\text { organizational goals. }\end{array}$ & & & & & & \\
\hline \multirow{3}{*}{ Trust } & Trust 1 & $\begin{array}{l}\text { Offering moral support } \\
\text { and help to employees } \\
\text { and colleagues in crises. }\end{array}$ & & & & & & \\
\hline & Trust 2 & $\begin{array}{l}\text { Interpersonal contact } \\
\text { and support amongst } \\
\text { employees. }\end{array}$ & & & & & & \\
\hline & Trust 3 & $\begin{array}{l}\text { Confiding in seniors } \\
\text { without fear of their } \\
\text { misusing trust. }\end{array}$ & & & & & & \\
\hline \multirow{3}{*}{ Authenticity } & Auth.1 & $\begin{array}{l}\text { Congruity between } \\
\text { feelings and expressed } \\
\text { behavior }\end{array}$ & & & & & & \\
\hline & Auth.2 & $\begin{array}{l}\text { Tactfulness, smartness } \\
\text { and even a little } \\
\text { manipulation to get } \\
\text { things done. }\end{array}$ & & & & & & \\
\hline & Auth.3 & $\begin{array}{l}\text { Owning up mistakes } \\
\text { made. }\end{array}$ & & & & & & \\
\hline
\end{tabular}




\begin{tabular}{|c|c|c|c|c|c|c|c|c|}
\hline \multirow{2}{*}{\multicolumn{3}{|c|}{ Construct/ Indicators }} & \multicolumn{5}{|c|}{ scale } & \multirow{2}{*}{ Origin } \\
\hline & & & 1 & 2 & 3 & 4 & 5 & \\
\hline \multirow[b]{2}{*}{ Pro-active } & Proact.1 & $\begin{array}{l}\text { Preventive actions on } \\
\text { most matters }\end{array}$ & & & & & & \\
\hline & Proact.2 & $\begin{array}{l}\text { Seniors encouraging } \\
\text { their subordinates to } \\
\text { think about their } \\
\text { development and take } \\
\text { action in that direction. }\end{array}$ & & & & & & \\
\hline \multirow{3}{*}{ Autonomy } & Auto 1 & $\begin{array}{l}\text { Employees taking } \\
\text { independent action } \\
\text { relating to their jobs }\end{array}$ & & & & & & \\
\hline & Auto 2 & $\begin{array}{l}\text { Close supervision of, } \\
\text { and directing } \\
\text { employees on, action. }\end{array}$ & & & & & & \\
\hline & Auto 3 & $\begin{array}{l}\text { Obeying and checking } \\
\text { with seniors rather than } \\
\text { acting on one's own }\end{array}$ & & & & & & \\
\hline \multirow[b]{2}{*}{ Confrontation } & Conf 1 & $\begin{array}{l}\text { Facing and not shying } \\
\text { away from problems. }\end{array}$ & & & & & & \\
\hline & Conf 2 & $\begin{array}{l}\text { Going deeper rather } \\
\text { than doing surface-level } \\
\text { analysis of interpersonal } \\
\text { problems. }\end{array}$ & & & & & & \\
\hline \multirow{2}{*}{ Experimentation } & Exp 1 & $\begin{array}{l}\text { Employees trying out } \\
\text { innovative ways of } \\
\text { solving problems }\end{array}$ & & & & & & \\
\hline & Exp 2 & $\begin{array}{l}\text { Encouraging employees } \\
\text { to take a fresh look at } \\
\text { how things are done. }\end{array}$ & & & & & & \\
\hline \multicolumn{9}{|c|}{ Workplace structure } \\
\hline \multirow[t]{2}{*}{ Support } & Sup 1 & $\begin{array}{l}\text { My co-workers (i.e., } \\
\text { other teachers) can be } \\
\text { relied upon when things } \\
\text { get tough. }\end{array}$ & & & & & & \multirow{4}{*}{$\begin{array}{l}\text { Bateman, Strasser (1984) } \\
\text { Becker et al. (1995) } \\
\text { Douglas B. Currivan. (1999) } \\
\text { Moser (1997) } \\
\text { Lau and Chong ( 2002) } \\
\text { Lambert (2004) } \\
\text { Hussin (2011) } \\
\text { Saari, Judge (2004) }\end{array}$} \\
\hline & Sup 2 & $\begin{array}{l}\text { My co-workers are } \\
\text { willing to listen to my } \\
\text { job-related problems }\end{array}$ & & & & & & \\
\hline \multirow{2}{*}{$\begin{array}{l}\text { Supervisor } \\
\text { support }\end{array}$} & Super 1 & $\begin{array}{l}\text { My co-workers are } \\
\text { helpful to me in getting } \\
\text { my job done. }\end{array}$ & & & & & & \\
\hline & Super 2 & $\begin{array}{l}\text { My administrator can } \\
\text { be relied upon when } \\
\text { thinks get tough on } \\
\text { my job. }\end{array}$ & & & & & & \\
\hline
\end{tabular}




\begin{tabular}{|c|c|c|c|c|c|c|c|c|}
\hline \multirow{2}{*}{\multicolumn{3}{|c|}{ Construct/ Indicators }} & \multicolumn{5}{|c|}{ scale } & \multirow{2}{*}{ Origin } \\
\hline & & & 1 & 2 & 3 & 4 & 5 & \\
\hline \multicolumn{9}{|l|}{ Job Satisfaction } \\
\hline \multirow{3}{*}{ Job Satisfaction } & JobSat.1 & $\begin{array}{l}\text { I find enjoyment in my } \\
\text { job. }(r)\end{array}$ & & & & & & \\
\hline & JobSat.2 & $\begin{array}{l}\text { Most days I am } \\
\text { enthusiastic about my } \\
\text { job. (r) }\end{array}$ & & & & & & \\
\hline & JobSat.3 & $\begin{array}{l}\text { I am often bored with } \\
\text { my job. }\end{array}$ & & & & & & \\
\hline \multicolumn{9}{|c|}{ Organizational Commitment } \\
\hline \multirow{3}{*}{$\begin{array}{l}\text { Organizational } \\
\text { Commitment }\end{array}$} & Com.1 & $\begin{array}{l}\text { The school in which I } \\
\text { work is the best of all } \\
\text { possible places to work. }\end{array}$ & & & & & & \\
\hline & Com.2 & $\begin{array}{l}\text { I do not care about the } \\
\text { fate of the school in } \\
\text { which I work. }\end{array}$ & & & & & & \\
\hline & Com.3 & $\begin{array}{l}\text { I speak highly of the } \\
\text { school in which I work } \\
\text { to my friends. }\end{array}$ & & & & & & \\
\hline \multicolumn{9}{|c|}{ Effective Performance } \\
\hline \multirow{3}{*}{$\begin{array}{l}\text { Effective } \\
\text { Performance }\end{array}$} & Per.1 & $\begin{array}{l}\text { My students' average } \\
\text { scores good rather } \\
\text { than others. }\end{array}$ & & & & & & \\
\hline & Per.2 & $\begin{array}{l}\text { My job, department } \\
\text { does high levels in the } \\
\text { school. }\end{array}$ & & & & & & \\
\hline & Per.3 & $\begin{array}{l}\text { My job always a high } \\
\text { level rather than others. }\end{array}$ & & & & & & \\
\hline
\end{tabular}

